\title{
ORIGINAL
}

\section{Synthesis and Properties of Bis (sulfonate) Types of Double-chain Surfactants Bearing a Sulfur Atom in the Connecting Part}

\author{
Yun-Peng Zhu, Araki MasuYama, Yohji NAKAtsuJi*, \\ and Mitsuo OKAHARA \\ Department of Applied Chemistry, Faculty of Engineering, Osaka University \\ (2-1, Yamadaoka, Suita-shi, $=565)$
}

\begin{abstract}
Double-chain diol compounds and double-chain bis(sulfonate) surfactants, each bearing a sulfur atom as a sulfide, sulfoxide, or sulfone in the middle of the connecting part between two alkyl chains, were prepared. The emulsifying properties of the double-chain diols were studied in a mixed system of liquid paraffin and water. The double-chain bis(sulfonate) compounds bearing two decyl groups as the lipophilic part were easily soluble in water. Some surface-active properties of the surfactants bearing a sulfur atom in the connecting part were examined along with a similar type of double-chain surfactant having an oxygen atom in place of a sulfur atom. Displacement of the ether oxygen in the middle of the connecting group by the sulfide sulfur atom caused a slight decrease in cmc. A bulky group such as sulfinyl or sulfonyl in the middle of the connecting part negatively affected the micelle forming properties and the capacity to lessen surface tension. The double-chain bis(sulfonate) surfactants showed much greater lime-soap dispersing ability than sodium 1-dodecanesulfonate.
\end{abstract}

\section{Introduction}

We have developed novel types of doublechain surfactants with two hydrophilic head groups, which belong to a new category of surfactant structure ${ }^{1) \sim 5)}$. We have noticed that the surface-active properties of these double-chain surfactants are dependent on three structural factors : 1 , the length of the alkyl chain, 2, the kind of hydrophilic group, and 3 , the structure of the connecting part between the two lipophilic chains. The third factor seems to be especially significant for the $\mathrm{cmc}$ and $\gamma_{\mathrm{cmc}}$ values. The structure of the connecting part arises from diepoxide compounds as one of the starting materials. The connecting parts that we have studies till now are derived from diepoxide compounds such as bis (2,3-epoxypropyl) ether, ethylene glycol-, di(ethylene glycol)-, tri (ethylene glycol)-, butylene glycol-, pyrocatechol- and hydroquinone diglycidyl

* Corresponding author: Yohji NAKATSUJI ethers. We chose these diepoxides from the viewpoints of the "length" and "flexibility" of the connecting part (Fig. -1).

In this work, with a view to exploring the structural effect of the connecting part on surface-active properties from another standpoint, we designed new double-chain bis (sulfonate) types of surfactants using a diglycidyl ether containing a sulfur atom as a starting compound. The valence of the sulfur atom can be easily changed by conventional reactions. We first synthesized a diol compound (1) bearing a thio group in the connecting part and then prepared bis (sulfonate) compound (2) from 1. Sulfinyl (5) and sulfonyl (6) derivatives bearing two sulfonate groups were obtained by the selective oxidation of 2. A sulfoxide-type diol (3) and a sulfone-type diol (4) were also afforded by the selective oxidation of 1 (Fig. $-2)$. We measured the surface-active properties of 2, 5, and 6 in water and compared these results with that of the corresponding 


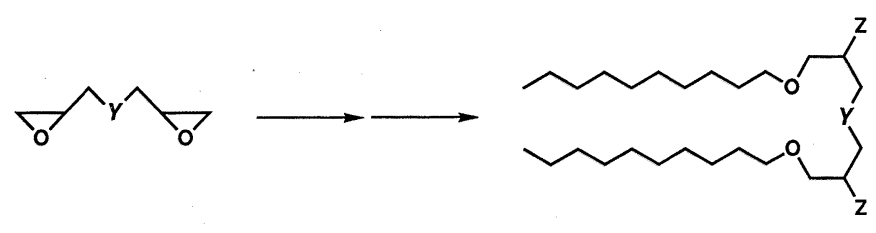

Diepoxide

Double-chain surfactants

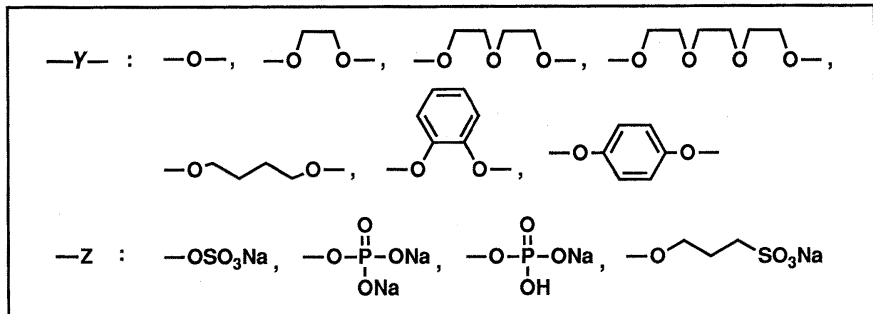

Fig.-1 A variety of double-chain surfactants derived from diepoxide compounds.

bis(sulfonate) compound with an oxygen atom in place of the sulfur atom in the connecting part (8, in Fig. - 2 ) to study the structural effect of the connecting group. Additionally, we employed double-chain diol compounds $(1,3,4$, and 7$)$ to run a preliminary experiment on their emulsifying properties. The preparative route for the studies compounds is shown in Fig. -2 .

\section{Experimental}

${ }^{1} \mathrm{H}-\mathrm{NMR}$ spectra were measured in $\mathrm{CDCl}_{3}$ with a JEOL JNM-GSX $400(400 \mathrm{MHz})$ spectrometer using TMS as an internal standard. The IR spectra and Mass spectra (including FAB-Mass) were recorded on a Hitachi 260 spectrometer and a JEOL JMS -DX 303 mass spectrometer, respectively. An $\mathrm{O} / \mathrm{W}$ emulsion system was prepared by the following recipe : A mixture of dioltype surfactant $(0.1 \mathrm{~g})$, liquid paraffin (Nacalai Tesque, Inc., extra pure grade, 4.0 $\mathrm{g})$, and water $(15.9 \mathrm{~g})$ was homogenized at $70^{\circ} \mathrm{C}$ for 3 min using a homogenizer (Polytron $^{\mathrm{R}}$ Model KR, 10,000 rpm). After leaving the mixture at ambient temperature for 5 min, the measurements were started. Stability of the prepared emulsion was evaluated by the ratio of the emusified-layer volume to the total volume of the mixture. The Krafft point $\left(\mathrm{T}_{\mathrm{Kp}}\right)$ was measured by the naked eye with a 1 wt $\%$ aqueous solution of surfactants. The surface tension of a surfactant solution was measured at $20^{\circ} \mathrm{C}$ with a Wilhelmy tensiometer (Shimadzu ST-1) using a glass plate. The $\mathrm{cmc}$ and $\gamma_{\mathrm{cmc}}$ values were determined from the break point of each surface tension vs. concentration (on log scale) curve. The foam properties were measured by the Semi-micro TK method ${ }^{6)}$. The lime-soap dispersing requirement (LSDR) was estimated in hard water with 333 ppm of the total hardness as $\mathrm{CaCO}_{3}$ by the Borghetty-Bergman method ${ }^{7}$.

2,2'-Thiodiethanol diglycidyl ether was synthesized under phase-transfer catalytic conditions according to the previously reported method of preparing di(ethylene glycol) diglycidyl ether ${ }^{8)}$. Sulfide-type diol 1 was prepared by the ring-opening reaction of the diglycidyl ether by potassium $n$-decanoate $^{9)}$. It was isolated by Kugelrohr distillation (bp : $160 \sim 170^{\circ} \mathrm{C} / 0.04$ Torr) in $65 \%$ yield $\left(\mathrm{mp}: 34.0 \sim 35.0^{\circ} \mathrm{C}\right.$ ).

Double-chain bis(sulfonate) compound (2) was synthesized by the reaction of 1 with 1,3-propanesultone in the presence of $\mathrm{NaH}$ in $\mathrm{THF}^{4)}$. The sulfoxide-type diol 3 and sulfone-type diol 4 were prepared by the reaction of 2 with equimolar $30 \mathrm{wt} \%$ hydrogen peroxide solution in a mixed solvent of benzene and ethanol below $10^{\circ} \mathrm{C}$ and with a twice molar amount of $30 \mathrm{wt} \%$ hydrogen peroxide solution under reflux conditions, 


<smiles>CCOCC(O)COCCSCCOCC(O)COCCO</smiles>


1
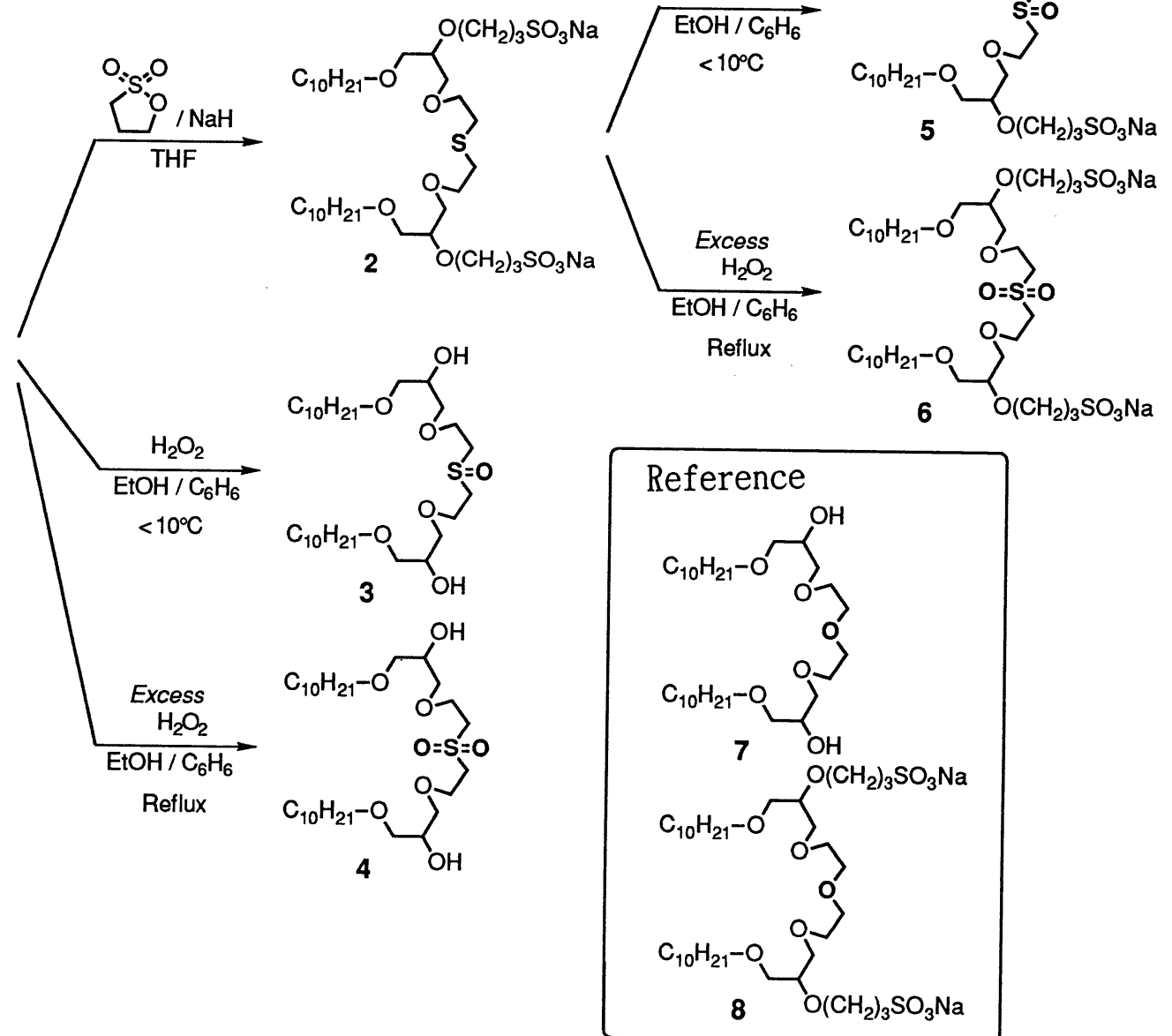

Fig.-2 Preparation route for double-chain diols $(1,3,4)$ and the corresponding bis (sulfonate) $\mathrm{s}(2,5,6)$ bearing a sulfur atom in the connecting part, along with the structures of reference compounds $(7,8)$. 
respectivey ${ }^{10)}$. Compound 2 was oxidized with $30 \mathrm{wt} \%$ hydrogen peroxide solution to give sulfoxide-type bis(sulfonate) compound (5) and sulfone-type bis (sulfonate) compound (6), respectively, under different conditions as described below.

Disodium 5,15-bis(2-oxadodecyl)-4,7,13, 16-tetraoxa-10-thia-1,19-nonadecanedisulfonate (2) : A solution of 1 (1.10 g, 2 $\mathrm{mmol})$ in THF $(10 \mathrm{~mL})$ was added to a stirred dispersion of $\mathrm{NaH}(60 \%)(0.33 \mathrm{~g}$ net, $8 \mathrm{mmol})$ in THF $(20 \mathrm{~mL})$ at $60^{\circ} \mathrm{C}$. After a solution of 1,3 -propanesultone $(0.74 \mathrm{~g}, 6$ $\mathrm{mmol})$ in THF $(10 \mathrm{~mL})$ was dropped into the mixture at $60^{\circ} \mathrm{C}$, the reaction was continued under reflux conditions until the TLC peak based on 1 disappeared ( $24 \mathrm{~h}$ ). Any excess of $\mathrm{NaH}$ was deactivated by addition of methanol $(5 \mathrm{~mL})$ at ambient temperature. This resultant mixture was dissolved in water $(60 \mathrm{~mL})$ and the aqueous solution was extracted with $n-\mathrm{BuOH}(3 \times 45 \mathrm{~mL})$. The extracts were combined and condensed under reduced pressure. Finally, the TLCpure product $2(0.80 \mathrm{~g})$ was isolated as white hygroscopic crystals in $48 \%$ yield by silica gel column chromatography of the obtained residue with a dichloromethane : methanol (100:5, vol/vol) eluent. IR (neat) $3500, \quad 2980, \quad 1240, \quad 1100 \mathrm{~cm}^{-1} ;{ }^{1} \mathrm{H}-\mathrm{NMR}$ $\left(\mathrm{CDCl}_{3}\right) \delta 0.88(\mathrm{t}, 6 \mathrm{H}), 1.10 \sim 1.65(\mathrm{~m}, 32$ $\mathrm{H}), 2.00 \sim 2.20(\mathrm{~m}, 4 \mathrm{H}), 2.70 \sim 2.78(\mathrm{~m}, 4$ $\mathrm{H}), \quad 2.95 \sim 3.15(\mathrm{~m}, 4 \mathrm{H}), 3.35 \sim 3.85(\mathrm{~m}, 22$ $\mathrm{H})$; Anal. Found : C, $51.00 ; \mathrm{H}, 8.88 ; \mathrm{S}$, $11.42 \%$. Calcd. for $\mathrm{C}_{36} \mathrm{H}_{72} \mathrm{O}_{12} \mathrm{~S}_{3} \mathrm{Na}_{2}: \mathrm{C}$, $51.53 ; \mathrm{H}, 8.65 ; \mathrm{S}, 11.46 \%$.

1,13-Bis(decyloxy)-7-oxo-4,10-dioxa-7 -thia-2, 12-tridecanediol (3) : Diol 1 (3.30 $\mathrm{g}, 6 \mathrm{mmol}$ ) was dissolved in a mixed solvent of benzene $(15 \mathrm{~mL})$ and ethanol $(5 \mathrm{~mL})$. Hydrogen peroxide solution (30 wt $\%)(0.80$ $\mathrm{g}, 7 \mathrm{mmol}$ ) was dropped into the mixture below $10^{\circ} \mathrm{C}$. The reaction mixture was then stirred below $10^{\circ} \mathrm{C}$ for $12 \mathrm{~h}$, followed by deactivation of any excess of hydrogen peroxide with $1.1 \mathrm{~g}$ of sodium thiosulfate. After evaporation of the mixture under reduced pressure, the residue was purified to give $2.58 \mathrm{~g}$ of the desired 3 in $76 \%$ yield by silica gel column chromatography using a hexane : ethanol ( $8: 1, \mathrm{vol} / \mathrm{vol})$ eluent. Mp. 42.5 43.7 ${ }^{\circ} \mathrm{C}$; IR (neat) 3500, 2980, 1240, 1000, 900 $\mathrm{cm}^{-1} ;{ }^{1} \mathrm{H}-\mathrm{NMR}\left(\mathrm{CDCl}_{3}\right) \delta 0.88(\mathrm{t}, 6 \mathrm{H})$, $1.21 \sim 1.60(\mathrm{~m}, 32 \mathrm{H}), 2.77(\mathrm{~s}, 2 \mathrm{H}), 2.98 \sim$ $3.10(\mathrm{~m}, 2 \mathrm{H}), 3.10 \sim 3.15(\mathrm{~m}, 2 \mathrm{H}), 3.40 \sim$ $3.80(\mathrm{~m}, 12 \mathrm{H}), 3.90 \sim 4.10(\mathrm{~m}, 6 \mathrm{H})$; FABMass ( $m / e$, relative intensity) : $589[(\mathrm{M}+$ $\left.\mathrm{Na})^{+}, 15\right], 567\left[(\mathrm{M}+1)^{+}, 100\right]$.

1,13-Bis(decyloxy)-7,7-dioxo-4,10-dioxa -7-thia-2,12-tridecanediol (4) : A mixture of $1(2.20 \mathrm{~g}, 4 \mathrm{mmol}), 30 \mathrm{wt} \%$ hydrogen peroxide $(0.91 \mathrm{~g}, 8 \mathrm{mmol})$, benzene $(5 \mathrm{~mL})$, and ethanol $(5 \mathrm{~mL})$ was refluxed for $5 \mathrm{~h}$. Evaporation of the reaction mixture gave a $2.50 \mathrm{~g}$ crude product, which was chromatographed on silica gel using hexane : acetone $(6: 1, \mathrm{vol} / \mathrm{vol})$ eluent to afford 4 $(2.05 \mathrm{~g})$ in $88 \%$ yield. Mp. $47.5 \sim 48.5^{\circ} \mathrm{C}$; IR (neat) $3500,2980,1300,1120,900 \mathrm{~cm}^{-1} ;{ }^{1} \mathrm{H}-$ $\mathrm{NMR}\left(\mathrm{CDCl}_{3}\right) \delta 0.88(\mathrm{t}, 6 \mathrm{H}), 1.20 \sim 1.56(\mathrm{~m}$, $32 \mathrm{H}), 2.78(\mathrm{~s}, 2 \mathrm{H}), 3.30 \sim 3.70(\mathrm{~m}, 16 \mathrm{H})$, $3.90 \sim 4.10(\mathrm{~m}, 6 \mathrm{H})$; FAB-Mass $(m / e$, relative intensity) : $605\left[(\mathrm{M}+\mathrm{Na})^{+}, 30\right], 583$ $\left[(\mathrm{M}+1)^{+}, 100\right], 137[85], 85[60], 57[100]$.

Disodium 10-oxo-5,15-bis(2-oxadodecyl) $-4,7,13,16$-tetraoxa-10-thia-1,19-nonadecanedisulfonate (5): Compound $2(2.51 \mathrm{~g}, 3$ $\mathrm{mmol})$ was dissolved in a mixed solvent of ethanol $(15 \mathrm{~mL})$ and water $(8 \mathrm{~mL})$. Hydrogen peroxide solution $(30 \mathrm{wt} \%)(0.45 \mathrm{~g}, 4$ $\mathrm{mmol}$ ) was dropped into the mixture below $10^{\circ} \mathrm{C}$. The reaction was continued below $10^{\circ} \mathrm{C}$ for $c a .20 \mathrm{~h}$, followed by deactivation of any excess of hydrogen peroxide with $0.63 \mathrm{~g}$ of sodium thiosulfate. Water $(50 \mathrm{~mL})$ was added to the resultant mixture and the aqueous solution was extracted with $n-$ $\mathrm{BuOH}(3 \times 45 \mathrm{~mL})$. After the extracts were combined and condensed under reduced pressure, the residue was dissolved in a 45 $\mathrm{mL}$ of chloroform : methanol (2:1, vol/ vol). The insoluble solids were filtered off by passage through a Celite 545 short column. After evaporation of the filtrate, TLC - pure target compound $5(1.58 \mathrm{~g})$ was isolated as white hygroscopic crystals in $62 \%$ yield by silica gel column chromatography of the residue using a chloroform : ethanol (7:1, vol/vol) eluent. IR (neat) 3500,2980 , $1240,1100 \mathrm{~cm}^{-1} ;{ }^{1} \mathrm{H}-\mathrm{NMR}\left(\mathrm{CDCl}_{3}\right) \delta 0.88(\mathrm{t}$, 
$6 \mathrm{H}), 1.10 \sim 1.65(\mathrm{~m}, 32 \mathrm{H}), 2.05 \sim 2.18(\mathrm{~m}, 4$ $\mathrm{H}), 2.90 \sim 3.20(\mathrm{~m}, 8 \mathrm{H}), 3.30 \sim 4.0(\mathrm{~m}, 22 \mathrm{H})$; Anal. Found : C, $50.21 ; \mathrm{H}, 8.82 ; \mathrm{S}, 11.22$ \%. Calcd. for $\mathrm{C}_{36} \mathrm{H}_{72} \mathrm{O}_{13} \mathrm{~S}_{3} \mathrm{Na}_{2}$ : C, $50.57 ; \mathrm{H}$, $8.49 ; \mathrm{S}, 11.25 \%$.

Disodium 10,10-dioxo-5,15-bis (2-oxadodecyl) $-4,7,13,16$ - tetraoxa-10-thia-1,19nonadecanedisulfonate (6): Hydrogen peroxide $(30 \mathrm{wt} \%)(0.90 \mathrm{~g}, 8 \mathrm{mmol})$ was dropped into the solution of $2(2.51 \mathrm{~g}, 3 \mathrm{mmol})$ in methanol $(15 \mathrm{~mL})$ at about $40^{\circ} \mathrm{C}$. The reaction mixture was stirred under reflux conditions for $10 \mathrm{~h}$. After evaporation of the resultant mixture, the residue was purified to give $6(1.55 \mathrm{~g})$ in $59 \%$ yield as colorless hygroscopic crystals by silica gel chromatography using a chloroform : ethanol (3:1, $\mathrm{vol} / \mathrm{vol}$ ) eluent. IR (neat) 3500, 2980, 1240, $1100 \mathrm{~cm}^{-1} ;{ }^{1} \mathrm{H}-\mathrm{NMR}\left(\mathrm{CDCl}_{3}\right) \delta 0.88(\mathrm{t}, 6 \mathrm{H})$, $1.20 \sim 1.55(\mathrm{~m}, 32 \mathrm{H}), 2.04 \sim 2.17(\mathrm{~m}, 4 \mathrm{H})$, $3.00 \sim 3.10(\mathrm{~m}, 4 \mathrm{H}), 3.40 \sim 4.00(\mathrm{~m}, 26 \mathrm{H})$; Anal. Found : C, 48.27 ; H, 8.23 ; S, $11.17 \%$. Calcd. for $\mathrm{C}_{36} \mathrm{H}_{72} \mathrm{O}_{14} \mathrm{~S}_{3} \mathrm{Na}_{2}$ : C, $49.64 ; \mathrm{H}$, $8.33 ; \mathrm{S}, 11.04 \%$.

Double-chain diol (7) and bis (sulfonate) compound (8) as reference compounds were prepared according to the method reported previously ${ }^{4}$.

\section{Results and Discussion}

Synthesis. There is another possible route for the preparation of sulfoxide-type bis (sulfonate) (5) and sulfone-type bis (sulfonate) (6) besides the route illustrated in Fig. -2. That is the reaction of sulfoxidetype diol 3 or sulfone-type diol 4 with 1 , 3 -propanesultone to afford 5 or 6 , respectively. We tried this reaction route using similar procedures to prepare sulfide-type bis(sulfonate) (2) from the corresponding diol 1. When sulfoxide-type diol 3 was treated with $\mathrm{NaH}$ in $\mathrm{THF}$, the resulting solution, distinctly different from that of sulfide-type diol 1, became dark brown. 1, 3-Propanesultone was added dropwise to this solution and a tar-like mixture was obtained as a crude product. At least more that 5 spots were observed in its TLC. Purification of the crude product was too difficult to isolate the target compound 5 . It is surmised that in the presence of a strong base like $\mathrm{NaH}$, deprotonation will occur at the methylene group adjacent to the sulfinyl group $^{11)}$ besides the deprotonation of the hydroxyl groups. The resultant "thioenolate" anion may attack 1,3-propanesultone to give many undesired by-products (Fig. $-3)$.

When sulfone-type diol 4 was reacted with 1,3-propanesultone in THF in the presence of $\mathrm{NaH}$, no tar-like mixture formed. After extraction and condensation according to a procedure similar to the preparation of 2, a chloroform solution $(30 \mathrm{~mL})$ of the resultant reaction mixture was passed through a Celite 545 short column. The filtrate was condensed, but its infrared spectrum showed no adsorption near $1240 \mathrm{~cm}^{-1}$ assigned to $\mathrm{S}=\mathrm{O}$ bond. Hence, the Celite was washed with ethanol and concentrated to afford $1.78 \mathrm{~g}$ of crude product as yellow semi-solids. Finally, 6 ( $0.85 \mathrm{~g})$ was isolated as a pale yellow crystal in $48 \%$ yield by silica gel chromatography of the crude product with the following gradient eluent system : $\mathrm{CHCl}_{3}: \mathrm{EtOH}$ (150:30, vol/vol), subsequent to $\mathrm{CHCl}_{3}: \mathrm{EtOH}: \mathrm{MeOH}$ (150: 40 : $10, \mathrm{vol} / \mathrm{vol})$.

Emulsion stability. Double-chain diol "precursors" (1, 3, 4, and 7) are oil-soluble nonionic surfactants themselves. So the emulsifying ability of these diols was evaluated in the $\mathrm{O} / \mathrm{W}$ emulsion system using liq-

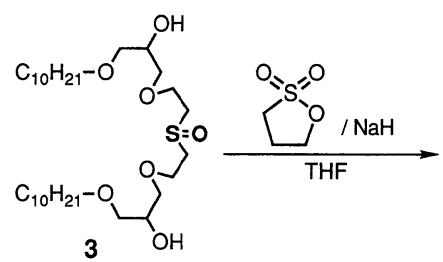

Mixture of many unseparable products
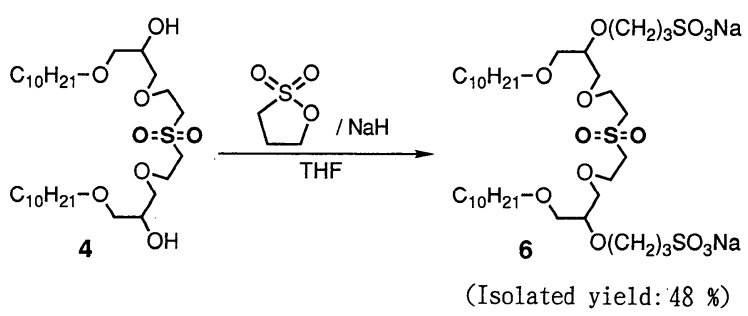

Fig. -3 Results of the reaction of 3 or 4 with 1,3propanesultone. 


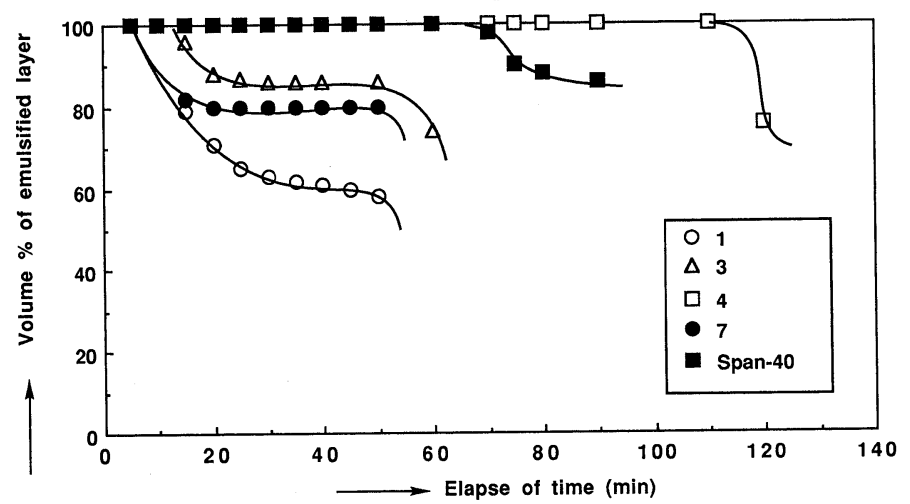

Fig. -4 The relation of volume $\%$ of $\mathrm{O} / \mathrm{W}$ emulsified layer and the elapse of time.

uid paraffin as the oil component. Fig. -4 illustrates the stability of the emulsion system along with the result of the commercial emulsifier, Span-40 (Sorbitan monopalmitate, Wako Pure Chemical Industries, Ltd.), under the same conditions. As can be observed from Fig. -4, the structure of the connecting group has a pronounced effect on the stability of the emulsion. It is roughly estimated that the stability of the emulsion decreased in the following order : $4>$ Span$40 \gg 3>7=1$. It is additionally noted that the sulfone-type diol 4 afforded higher stability of the emulsion than Span-40, which is known as a good emulsifier. Since the behavior of emulsion systems constructed by surfactants is affected by various factors, it is hard to evaluate the emusifying ability of these new diols based on the present experimental results only. We plan to explore the emulsifying properties of these diols in various emulsion systems and to discuss where the HLB of these diols is located among a series of existing nonionic emulsifiers.

Surface-active properties. Since doublechain sulfonate compounds $(2,5,6$, and 8) were readily soluble in water even below 0 ${ }^{\circ} \mathrm{C}$, their Krafft points are below $0{ }^{\circ} \mathrm{C}$. In comparison with a typical single-chain reference, sodium 1-dodecanesulfonate (Krafft point : $\left.39^{\circ} \mathrm{C}\right)^{4}$, these double-chain sulfonate compounds have higher water solubility. This may be attributed to the cooperative contributions of the two sulfonate groups and the presence of ether oxygen atoms and thio, sulfinyl or sulfonyl groups in the connecting part to water solubility as previously explained ${ }^{1) \sim 4)}$

The surface-tension $v s$. concentration (on log scale) curves in deionized water are shown in the upper graph of Fig. -5 . The $\mathrm{cmc}$ and $\gamma_{\mathrm{cmc}}$ values and the efficiency of adsorption at the surface $\left[\mathrm{pC}_{20}\right.$, the negative

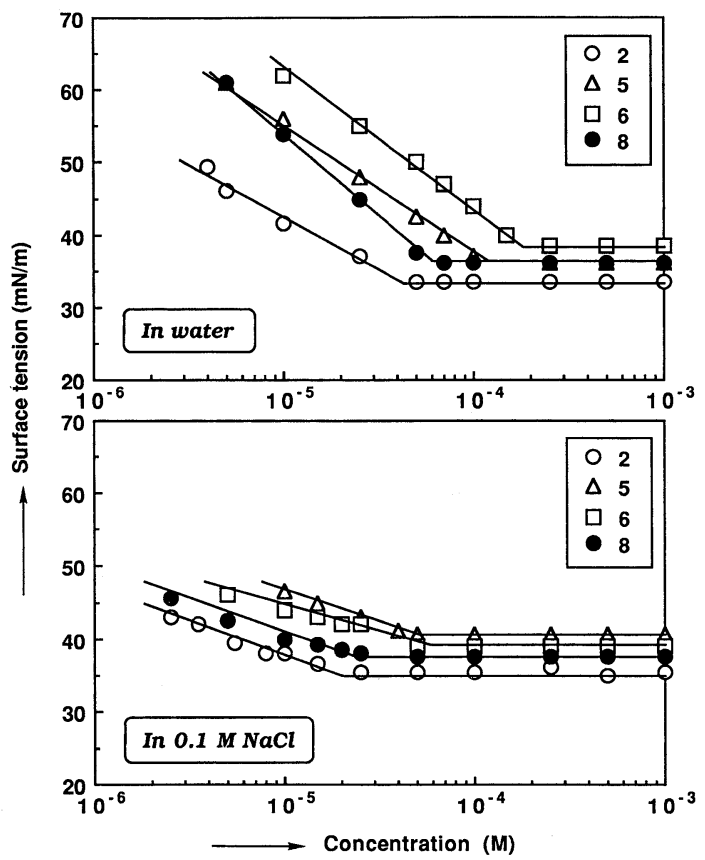

Fig. -5 Surface tension vs concentration plots of surfactants 2, 5, 6, and 8 in deionized water (above) and in $0.1 \mathrm{M} \mathrm{NaCl}$ solution (below) at $20^{\circ} \mathrm{C}$. 
Table-1 The results of $\mathrm{cmc}, \gamma_{\mathrm{cmc}}$ and $\mathrm{pC}_{20}$ of compounds $2,5,6,8$, and sodium 1 -dodecanesulfonate in deionized water at $20^{\circ} \mathrm{C}$.

\begin{tabular}{cccc}
\hline Compound & $\begin{array}{c}\mathrm{cmc} \\
(\mathrm{mM})\end{array}$ & $\begin{array}{c}\gamma_{\mathrm{cmc}} \\
(\mathrm{mN} / \mathrm{m})\end{array}$ & $\mathrm{pC}_{20}$ \\
\hline 2 & 0.044 & 33.5 & 5.7 \\
5 & 0.11 & 36.0 & 4.8 \\
6 & 0.20 & 38.5 & 4.4 \\
$8^{\mathrm{a}}$ & 0.060 & 36.0 & 4.9 \\
\hline $\mathrm{C}_{12} \mathrm{H}_{25} \mathrm{SO}_{3} \mathrm{Na}^{\mathrm{b}}$ & 9.8 & 39.0 & 2.5 \\
\hline
\end{tabular}

a) Ref. 4 .

b) Measured at $45^{\circ} \mathrm{C}$.

$\log$ of $\mathrm{C}_{20}$, the surfactant molar concentration required to reduce the surface tension by $20 \mathrm{mN} / \mathrm{m}^{12)}$ ] of these double-chain surfactants are listed in Table-1, along with the data for sodium 1-dodecanesulfonate.

The $\mathrm{cmc}$ values of all these double-chain sulfonate compounds are lower than that of sodium 1-dodecanesulfonate, suggesting that the double-chain surfactants have higher micelle forming ability. It appears that the difference in the middle group of the connecting part ( $\mathrm{S}, \mathrm{SO}, \mathrm{SO}_{2}$, or $\mathrm{O}$ ) greatly influences the cmc values. The increasing order of cmc is : $2(\mathrm{~S})<8(\mathrm{O})<5(\mathrm{SO})<6$ $\left(\mathrm{SO}_{2}\right)$. This result indicates that increasing the bulkiness of the middle group in the connecting part increases the $\mathrm{cmc}$ values of these types of double-chain surfactants. In addition, the difference in the polarity of the connecting part must be taken into account for explanation of the difference in their $\mathrm{cmc}$ values because the polarity of the molecule is concerned with the hydrophilicity (or lipophility) of the molecule, which strongly affects the micelle formation. For example, the dipole moment values of dimethyl sulfoxide and dimethyl sulfone are 2.3 D and $4.5 \mathrm{D}$, respectively, which are larger than these of dimethyl ether and dimethyl sulfide $(1.3 \mathrm{D} \text { and } 1.5 \mathrm{D} \text {, respectively })^{13)}$. So it is surmised that sulfonyl and sulfinyl groups make a stronger contribution to the hydrophility of the molecule than sulfide and ether oxygen atoms. Larger $\mathrm{cmc}$ values of 5 and 6 compared with 2 and 8 are also reasonable with respect to the difference in the hydrophility of the connecting part.

The plots of surface tension vs concentration (on log scale) of compounds 2, 5, 6, and 8 in the presence of a swamping electrolyte ${ }^{14)}$ $(0.1 \mathrm{M} \mathrm{NaCl})$ are also shown in the lower graph of Fig. -5 . The $\mathrm{cmc}$ values of compounds 2, 5, 6, and 8 in $0.1 \mathrm{M} \mathrm{NaCl}$ are 0.020 $\mathrm{mM}, 0.056 \mathrm{mM}, 0.060 \mathrm{mM}$, and $0.024 \mathrm{mM}$, respectively. All of these $\mathrm{cmc}$ values are lower than the values in deionized water. These results are explained by considering that thickness of the ionic atmosphere surrounding the anionic head groups is decreased by the additional electrolyte, and the electrical repulsion between head groups in the micelle consequently decreases ${ }^{15)}$. From the slope of each plot in the concentrations below its $\mathrm{cmc}$, the area per molecule (A) values of 2, 5, 6, and 8 at the surface are estimated at about $112 \AA^{2}, 116$ $\AA^{2}, 132 \AA^{2}$, and $115 \AA^{2}$, respectively, using the Gibbs adsorption equation in the presence of swamping electrolyte ${ }^{16)}$. The "A" value of 6 bearing a sulfonyl group is larger than the values of the others, clearly reflecting the bulkiness of the sulfonyl group. Their "A" values are about twice the value for the single-chain sodium 1-dodecanesulfonate $\left(57 \AA^{2} \text { in } 0.1 \mathrm{M} \mathrm{NaCl} \text { at } 25^{\circ} \mathrm{C}\right)^{17)}$. Therefore, the packing density of these surfactant molecules at the surface is probably similar to that of the corresponding single-chain surfactant.

It appears that the $\gamma_{\mathrm{cmc}}$ values also depend on the structure of the connecting group. The increasing order of $\gamma \mathrm{cmc}$ in water is $2<8=5<6$, reflecting the bulkiness of the middle group in the connecting part to a certain degree. In our studies on a series of double-chain surfactants derived from oligo (ethylene glycol) diglycidyl ethers ${ }^{2) \sim 4)}$, it has been clarified that the $\gamma_{\mathrm{cmc}}$ values increase with an increase in the length of the connecting part. Higher $\gamma_{\mathrm{cmc}}$ values reflect a loosely packed adsorption at the surface. As also expected from the higher value of area per molecule at the surface, the Van der Waals interaction of the lipophilic chain between the adsorbed molecules of 6 at the surface will be weaker than the others. It is 
concluded that not only the length but also the steric bulkiness of the connecting group affects the ability to lower surface tension.

The $\mathrm{pC}_{20}$ values of double-chain compounds $2,5,6$, and 8 were much higher than that of the reference single-chain surfactant. This tendency, which has also been observed for other double- or triple-chain compounds ${ }^{18), 19)}$, indicates that the efficiency of adsorption of these types of doublechain surfactants is very high. Among the compounds 2, 5, 6 and 8, compound 2 with a sulfide sulfur atom in the connecting part shows somewhat higher efficiency of adsorption than the others. As a conclusion, insertion of a bulky group into the connecting part makes a negative contribution to the hydrophobic interaction between the alkyl chains of double-chain surfactants, so that it lowers the micelle-forming property, the ability to lower surface tension, and the efficiency of adsorption.

Foaming properties and lime-soap dispersing requirement (LSDR) are summarized in Table-2.

It appears that foam stability rather than foaming ability strongly depends on the structure of the middle group in the connecting part. Compound 6 with a sulfonyl group showed higher foam stability than the others. Though the reason for this has not been clarified, it is noteworthy that the

Table-2 Foaming properties and LSDR of compounds $2,5,6,8$, and sodium 1 -dodecanesulfonate at $20^{\circ} \mathrm{C}$.

\begin{tabular}{cccc}
\hline Compound & \multicolumn{3}{c}{ Foam volume $(\mathrm{mL})^{\mathrm{a}}$} \\
& $0^{\prime}$ & $5^{\prime}(\mathrm{min})$ & LSDR $^{\mathrm{b}}$ \\
\hline $\mathbf{2}$ & 260 & $40^{\mathrm{a}}$ & 7.7 \\
$\mathbf{5}$ & 260 & 50 & 6.1 \\
$\mathbf{8}^{\mathrm{c}}$ & 270 & 260 & 7.3 \\
\hline $\mathrm{C}_{12} \mathrm{H}_{25} \mathrm{SO}_{3} \mathrm{Na}$ & 250 & 0 & 6.6 \\
\hline
\end{tabular}

a) Measured at $0.1 \mathrm{wt} \%$ except for sodium 1dodecanesulfonate $\left(1 \mathrm{wt} \%, 45^{\circ} \mathrm{C}\right)$.

b) Measured at 0.25 wt $\%$ aq. surfactant solution at $20^{\circ} \mathrm{C}$ except for sodium 1 -dodecanesulfonate $(0.5$ wt \%).

c) Ref. 4 . foam formed by compound 6 was apparently viscous in comparison with other foams. The difference in LSDR values for 2, 5, 6 and 8 is within experimental error, and the lime-soap dispersing ability of these double - chain surfactants is good compared with that of sodium 1-dodecanesulfonate. The hydrophilic part inclusive of the connecting group of these double-chain surfactants is considered to be bulky. It is reported that a bulky hydrophilic part is an important structural factor for an effective lime-soap dispersing agent ${ }^{2), 4), 20)}$.

(Received July 29, 1992)

\section{References}

1) M. Okahara, A. Masuyama, Y. Sumida, and Y-P. Zhu, J. Jpn. Oil Chem. Soc. (YUKAGAKU), 37, 716 (1988).

2) Y-P. Zhu, A. Masuyama, and M. Okahara, J. Am. Oil Chem. Soc., 67, 459 (1990).

3) Y-P. Zhu, A. Masuyama, and M. Okahara, J. Am. Oil Chem. Soc., 68, 268 (1991).

4) Y-P. Zhu, A. Masuyama, T. Nagata, and M. Okahara, J. Jpn. Oil Chem. Soc. (YUK$A G A K U), 40,473$ (1991).

5) A. Masuyama, T. Hirono, Y-P. Zhu, M. Okahara, and M. J. Rosen, J. Jpn. Oil Chem. Soc. (YUKAGAKU), 41, 301 (1992).

6) W. Yano and W. Kimura, Yukagaku, 11, 138 (1962).

7) H.C. Borghetty and C.A. Bergman, J. Am. Oil Chem. Soc., 27, 88 (1950).

8) X-P. Gu, I. Ikeda, and M. Okahara, Synthesis, 1985, 649.

9) Y. Nakatsuji, Y. Tsuji, I. Ikeda, and M. Okahara, J. Org. Chem., 51, 78 (1986).

10) I. Ikeda, Y. Tsuji, Y. Nakatsuji, and M. Okahara, J. Org. Chem., 51, 1128 (1986).

11) A. Muller and B. Krebs, "Sulfer : Its Significance for Chemistry, for the Geo-, Bioand Cosmoaphere and Technology", Elsevier, New York (1984) p. 111.

12) M.J. Rosen, "Surfactants and Interfacial Phenomena", 2nd Ed., John Wiley \& Sons, New York (1989) p. 85.

13) Japan Chemical Society, "Kagaku Binran, Kiso-hen II ", 3rd Ed., Maruzen, Inc., (1984) p. 720 ; T. Asahara et al., "Yohzai Handbook”, Kodansha (1976) p. 759 and p. 765.

14) Ref. 12) p. 66.

15) Ref. 12), p. 137. 
16) Ref. 12), p. 67.

17) M. Dahanayake, A.W. Cohaen, and M.J. Rosen, J. Phys. Chem., 90, 2413 (1986).

18) Y-P. Zhu, A. Masuyama, Y. Kirito, and M. Okahara, J. Am. Oil Chem. Soc., 68, 539 (1991).

19) Y-P. Zhu, A. Masuyama, Y. Kirito, M. Okahara, and M.J. Rosen, J. Am. Oil Chem. Soc., 69. 626 (1992)

20) W.M. Linfield, “Anionic surfactants, Part II ", Marcel Dekker, Inc., New York (1976) p. 2.

連結部に硫黄原子を含む二鎖ビス（スル ホン酸塩）型界面活性剂の合成と物性

朱 云鵬 - 益山新樹 - 中辻洋司・岡原光男

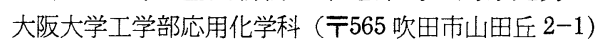

二つのアルキル鎖をつなぐ連結部の中央に，スルフィ ド，スルホキシド，あるいはスルホン構造の形で硫黄原 子を含む二鎖型ジオール化合物及び二鎖ビス（スルホン 酸塩）型界面活性剤を合成した。二鎖型ジオール化合物 の乳化特性を流動パラフィンー水混合系で評価した。二 本のデシル基を有する二鎖ビス(スルホン酸塩)型化合物 は容易に水に溶けた。これらの二鎖型界面活性剂と, 硫 黄原子の代わりに酸素原子を連結部に有する対応する構 造の二鎖型化合物の種々の界面活性能を検討した結果, 連結部中央のエーテル酸素原子をスルフィド硫黄原子で 置換することにより, 臨界ミセル浱度が低下することが 認められた。連結基中央部のスルフィニル基やスルホニ ル基のような立体的にかさ高い構造は, ミセル形成能や 表面張力低下能に対して不利な寄与をすることがわかっ た。これらの二鎖ビス(スルホン酸塩) 型界面活性剤は, 1ードデカンスルホン酸ナトリウムよりも良好なカルシ ウムセッケン分散力を示した。連絡者 : 中过洋司 